\title{
A SZEGÉNYSÉG ELLENI PROJEKTEK HASZNA. A KISVÁROSI SZOCIÁLIS FÖLDPROGRAM PÉLDÁJA
}

\section{THE PROFIT OF ANTI-POVERTY PROJECTS. THE CASE OF A SOCIAL LAND USE PROGRAM IN A RURAL TOWN}

\author{
Csurgó Bernadett ${ }^{1}$, Kovách Imre² \\ 'PhD, tudományos főmunkatárs, MTA Társadalomtudományi Kutatóközpont Szociológiai Intézet \\ Csurgo.Bernadett@tk.mta.hu \\ ªz MTA doktora, tudományos tanácsadó, egyetemi tanár, MTA Társadalomtudományi Kutatóközpont Szociológiai Intézet, \\ Debreceni Egyetem \\ Kovach.Imre@tk.mta.hu
}

\begin{abstract}
ÖSSZEFOGLALÁS
Tanulmányunkban egy kisvárosi, projektalapú szociális földprogram szereplőinek érdekeit és céljait, a részvétel és motiváció mértékét és formáit mutatjuk be. Arra keresünk választ, hogy milyen "hasznot" hozhatnak ezek a programok a helyi társadalom különböző csoportjai számára, és mi határozza meg a szociális célú program helyi elfogadását és elismerését. Hogyan hat egy innovatív szociális földprogram a szegények társadalmi integrációjára, és hogy a helyi társadalom más szereplői, köztük a helyi elit, hogyan válik érdekeltté és motiválttá a programok létrehozásában és fenntartásában? Eredményeink azt mutatják, hogy a hatalmi és kulturális integráció, amelyben a szegénység elleni programoknak lényeges gyakorlati és szimbolikus funkciójuk van, a helyi társadalom szinte összes csoportjának az érdeke és haszna.
\end{abstract}

\section{ABSTRACT}

The paper presents the forms and measures of interests, roles, participation and motivation of the participants of a project based land use program in a rural Hungarian town. We seek to understand how the different local society members can benefit from these programs, and what the basis of the local acceptance and acknowledgment are. How the social integration of local poverty might be influenced by an innovative social land use program and how the local elite and other groups of the local society can be motivated for participation and operation? Our results show that the local political and cultural integration in which the anti-poverty programs have practical and symbolic functions are important and profitable for all groups of local society.

Kulcsszavak: szociális földprogram, helyi érdek, identitás, integráció

Keywords: social land use program, local interest, identity, integration 
Tanulmányunkban egy kisvárosi projektalapú szociális földprogram szereplőinek érdekeit és céljait, a részvétel és motiváció mértékét és formáit mutatjuk be. Arra keresünk választ, hogy milyen „hasznot” hozhatnak ezek a programok a helyi társadalom különböző csoportjai számára, és mi határozza meg a szociális célú program helyi elfogadását és elismerését. Milyen célok, érdekek és motivációk határozzák meg a helyi szociális és társadalompolitikai programokat? Hogyan hat egy innovatív szociális földprogram a szegények társadalmi integrációjára és identitására, önképére, a közösségen belüli megítélésére, és hogy a helyi társadalom más szereplői, köztük a helyi elit, hogyan válik érdekeltté és motiválttá a programok létrehozásában és fenntartásában?

A szociális földprogramot a társadalmi innováció elméleti keretében értelmezzük. A társadalmi innovációt a szakirodalom olyan tevékenységként definiálja, amely egy társadalmi probléma, például a szegénység, újszerủ megoldására, enyhítésére irányul. A társadalmi innovációnak három dimenziója, eleme van, amelyben az innováció, újítás megragadható: a tartalom, a folyamat és a következmény. A társadalmi innováció valamilyen hiányzó társadalmi szükséglet kielégítésére vállalkozik. A társadalmi kapcsolatok és különös tekintettel a kormányzás megváltoztatását célozza azzal, hogy növeli a társadalmi csoportok, különösen a hátrányos helyzetűek, részvételét. A kimenetelt tekintve a társadalmi innováció lényege, hogy a társadalmi-politikai képességek fejlesztésével és megerösítésével növeli az erőforrásokhoz való hozzáférés esélyét (Moulaert et al., 2005). Annak ellenére, hogy a tudományos elemzésekben a kormányzás központi eleme a társadalmi innováció definíciójának, a közszférát vagy állami szektort alapvetően külső, nem ritkán negatív szereplőként fogják fel, és a társadalmi innováció föszereplőinek inkább a civil szervezeteket, a harmadik szektort tartják (Hillier, 2013; Pradel Miquel et al., 2013). Más írások viszont arra is rámutatnak, hogy a projekt kormányzási technikává vált, és ösztönzőleg hathat a kreativitásra és az innovációra (Kovách-Kucerova, 2006, 2009; Sjöblom, 2006; Czibere, 2013). A szakirodalom mégis kevés figyelmet szentel a közszférában dolgozók innovációs képességeinek és szervezési potenciáljuk hasznosítási lehetőségeinek. A közpolitikai intézkedések is válhatnak a társadalmi innováció hatékony segítőivé, ami az érintettek, bevontak közötti új kapcsolatok kialakulásához és a közszféra más szereplöi együttműködésen alapuló gyakorlatának elterjedéséhez vezethet (Levesque, 2013). A tanulmány arról szól, hogyan és milyen következmények kel valósítható meg a közszféra képviselőinek irányításával a pályázati programokat (projekteket) felhasználó innováció. A közszféra azon szereplöi a legérdekesebbek, akik mindennapi kapcsolatban vannak a társadalom legsérülékenyebb csoportjaival, és kulcsszerepük van a szegénység enyhítését célzó programokban. 
A helyszín Hajdúnánás ${ }^{1}$, a 17 000-18 000 fös kisváros, ahol az agrártermelés gazdaságtörténeti súlya hatással van a jelenlegi szociálpolitikai programokra is. A 19. században és a 20. század első felében a nagybirtok hiánya, a nagyszámú kis- és középgazdaság, a kisebb feldolgozóipar és a viszonylag kiegyenlített társadalomstruktúra volt a helyi gazdaság és társadalom jellegzetessége. A város a szocializmus idején agráripari településsé vált, és a mezőgazdasági kistermelésnek jelentős szerepe volt a társadalmi hátrányok ellentételezésében. Ezt a gazdasági és társadalmi struktúrát alakította át a föld- és egyéb privatizáció, melynek eredményeként jelenleg hat gazdaság használatában van a termőföld $42 \%$-a, és a 100 hektár feletti gazdaságok 55\%-ának használatában van a földek kétharmada (Kovách, 2016). A rendszerváltás és a gazdasági szerkezetváltás eredményeként jelent meg a tömeges szegénység a városban, ahol az átlaghoz viszonyított szélsőséges szegénység és társadalmi leszakadás soha sem volt igazán kiterjedt. A társadalomszerkezet az ezredfordulóra erősen szegmentálódott, és a munkanélküliség 2010-re már 10\%-os volt. A településen élő 3300-3400 gyermek gyakorlatilag fele valamilyen segélyezésben részesül (Franklin et al., 2017). Néhány éve felgyorsult a lakosság csökkenése, ma közel kétezerrel élnek kevesebben a településen, mint az 1990-es évek elején.

2010 után jelentős váltás következett a helyi társadalom- és szociálpolitikában. A szegénység enyhítése korábban gyakorlatilag sikertelen volt. A konzervatív többséghez vezető helyi hatalmi váltás után a szegénység enyhítésének és kezelésének a szándékával született meg a szociális földprogram. A rászorultak élelmezésének egy részét az önellátó mezőgazdasági tevékenység elindításával szándékozták elérni, amelyre célként és eszközként is tekintettek a szegénység következményének a mérséklésében.

A termelés, földhasználat és mezőgazdaság központi helyet foglal el a város többi szociális kezdeményezésében is. 2012 óta a START közmunkaprogram keretében döntően mezőgazdasági termelés és élelmiszer-feldolgozás zajlik a településen. Létrehoztak egy helyi terméket elöállító szociális szövetkezetet, valamint termelöi piacot, ahol a szociális szövetkezet és helyi gazdák termékeit árulják. „Nánási Portéka” néven állítottak össze helyi védjegyü élelmiszercsomagot, és ezt mutatják be a régió vásárain és bemutatóin. A közmunkaprogram keretében körülbelül 170 főt foglalkoztatnak 2012 óta. A város saját gazdaságot is müködtet, amelynek termékeit a közétkeztetési intézményeknek adják el, illetve egy szintén projektpénzből létrehozott konzervüzemben dolgozzák fel, közmunkásokkal is.

A közmunkaprogramot egészíti ki a résztvevők számát tekintve kisebb, de egyedi és újszerü kezdeményezésként a szociális földprogram (Franklin et al., 2017). 2010-ben a polgármester ösztönzésére, a helyi Családsegítő Központ két

\footnotetext{
${ }^{1}$ Köszönettel tartozunk Megyesi Boldizsárnak és Oláh-Pucsok Eszternek a témában készített interjúkért.
} 
vezető, szociális szakember munkatársa szociális földprogramot indított. A program alapkoncepciója és részben finanszírozása is az Emberi Erőforrások Minisztériuma Konyhakerti és kisállattartási szociális földprogram pályázati programjához kötődik. A programot a kezdetektől, tehát 2010 óta a Családsegítő Központ szervezi és koordinálja. A program beindítását megelőzően a helyi szociális szakemberek felmérték az igényeket, és kidolgozták a helyi szociális földprogram koncepcióját, valamint az önkormányzat is módosította a helyi szociális rendeletét, hogy adaptálni tudja a szociális földprogramot az önkormányzati ellátás rendszerébe, azaz hogy természetbeni támogatásként földhasználati lehetőséget, mezőgazdasági szolgáltatást és juttatást is nyújthasson a rászorulóknak.

„Nagy előny volt, hogy a város vezetése meglátta azt, hogy vannak magának a szociálpolitikának kézzel fogható elemei, amik tényleg nem arra támaszkodnak, hogy a rendszer folyamatosan csak tesz, pumpál bele, és azok a segítségformák tủzoltó jellegúek, hanem valamennyivel hosszabb távú megoldást nyújt, még ha annyival is hogy egy téli ciklust átvisz vele az egyén. Tehát nem kell folyamatosan a segélyek adásán gondolkozni, hanem itt egy kevesebb segélyt már igénybe tud venni, mert nem fog menni, kérni, mert van mit ennie..." (interjú, programirányító)

Indulásként az önkormányzat 2011-ben 1 millió Ft keretösszeget különített el a költségvetéséből a szociális földprogram megszervezésére, amit a későbbiekben pályázati forrásokkal bővítettek, tartottak fent. 2012-ben például 500000 Ft-ot 2013-ban pedig 950000 Ft-ot nyert a program vetömagra. 2011-ben 2 hektár, 2012-ben már 4 hektár önkormányzati tulajdonú földterületen a családmérettől függően 500 vagy 800 négyzetméteres parcellákon kezdődött meg a termelés. A saját konyhakert megmüvelésével is be lehetett kapcsolódni a programba. Az önkormányzat a termeléshez szükséges erőgépeket is vásárolt, valamint 5000 , illetve 8000 Ft értékü egységes vetőmagcsomag-támogatást is biztosított a programban résztvevőknek. Kezdetben saját fogyasztásra termeltek konyhakerti zöldségeket, ami 2012-től kiegészült a kisállattartási alprojekttel, melynek keretében a résztvevők húsz csirkét kaptak tenyésztésre.

2011-ben 57 családból 30 önkormányzati, 27 saját területen gazdálkodott. 2012re 73 családra emelkedett a létszám. 37 család önkormányzati földet, 36 pedig saját tulajdonú területet müvelt. 2012-től a kisállattartási alprojektben 179 család vett részt. 2013-ban 150 család a konyhakerti, 200 pedig a kisállattartási programban vett részt. Minden termelési időszak végén statisztikát készít a Családsegítő Központ. A megtermelt termékeket forintosítják, és így követik nyomon, hogy mennyi bevételt termeltek a családok termelési ciklusonként.

A szociális földprogram Hajdúnánáson integráns részévé vált a helyi szociálpolitikának. A program célcsoportját döntően a programot irányító Családsegítő 
Központ kliensei alkotják, így a program már egy meglévő kapcsolatrendszerre épül rá, a munkatársak minden résztvevőt személyesen ismernek. Ugyanakkor a központ számára a program új típusú, többletfeladatként jelenik meg. A résztvevők kiválasztása szociális alapon (nagycsaládosok, alacsony jövedelmüek) történik. Ezért a jelentkezést jövedelemvizsgálat előzi meg, majd a bekerülési kérelmeket egy környezettanulmánnyal kiegészítve a Családsegítő Központ bírálja el. A kiválasztott részvevőkkel a Családsegítő Központ köt támogatási szerződést, valamint a résztvevőket családgondozásba is veszik.

A programot a kezdetektől nagy érdeklődés övezte. Az első évben az akkori felmérések szerint 157 potenciális családból 57 család vett részt a programban, amelyböl 30 a közös önkormányzati földön kapott parcellát, 27 pedig a saját telkén termelt. A résztvevők száma kezdetben nőtt, majd beállt egy stabil szintre, 2015-ben már 179 család vett részt a programban.

A program mindig egy termelési ciklusra vonatkozik. Része a természetbeni támogatás (vetemény, állat, föld, munkagép) mellett a rendszeres szakmai tanácsadás és a havi kétszeri családlátogatás is. Emellett a programmal párhuzamosan egyéni esetkezelést is folytatnak, azaz a program elején minden résztvevő számára készítenek egy cselekvési tervet, amelyben megfogalmazzák a rövid és a hosszú távú célokat, amelyeket időnként kiértékelnek. A rövid távú cél általában a termelés megvalósítása, a hosszú távú cél pedig a hátrányos helyzet csökkentése, felszámolása, a munkaerőpiaci reintegráció és/vagy a termelés hosszú távú fenntartása.

A program indulásakor számos nehézséggel szembesültek a kezdeményezők és a résztvevők is. A helyi közvélemény kezdetben ellenérzésekkel, sokszor elutasítással fogadta a programot. Az elit és a lakosság más csoportjai sem hittek a program sikerében, pontosabban abban, hogy a helyi szegények valóban akarnak és képesek termelőmunkát végezni. Kezdetben a helyi sajtó és közbeszéd tele volt szkeptikus megjegyzésekkel a programmal kapcsolatosan, úgymint a szegények majd megeszik a vetőmagot és a napos csirkét, kár erre pénzt költeni a városvezetésnek. Az elismerésért és elfogadásért közösen kellett megküzdeniük a programot irányítóknak és a részt vevő szegényeknek. Mindez pedig erőteljes elköteleződéshez és bevonódáshoz vezetett, nemcsak a részt vevő szegények, de a programot irányító szociális szakemberek részéről is. És mindez, végső soron, hozzájárult a program sikeréhez.

„Meg kellett küzdenem több vezetővel is, illetve egyszerü emberekkel is, akik tulajdonképpen újságcikkek, tévériportok alapján azt mondták, hogy úgy is megeszik a gumókat, meg a napos csirkét megfőzik, meg eladják, meg italra cserélik, meg minden volt. Tehát a város azt mondta, hogy nem kell ezeknek a leírt társadalmi rétegeknek semmi sem. Nem kell ilyennel foglalkozni, nem kell ezt a két hektárt odaadni, meg az, hogy még egy millió forintért még vá- 
sárolunk is nekik. Körülbelül ez volt a hozzáállás, meg úgysem lesz ennek sikere. De ez teljesen mindegy, az egyszerü embertől kezdve, a vezetésig vagy hivatalokig, mindenhol voltak ilyen emberek, akik ellenálltak. És egyetlen egy módja volt, hogy az első évben tényleg minden szabadidőnket erre fordítottuk, hogy sikeres legyen, mert csak így tudtuk bizonyítani, hogy van ennek itt létjogosultsága, meg nagyon szégyelltük is volna magunkat, ha nem sikerül, az meg a másik." (interjú, programirányító)

A program középpontjában a termelés áll, s bár a helyi identitás erőteljes eleme a paraszti/gazdálkodói múlt és jelen, a termeléshez szükséges tudással sokan már nem rendelkeztek, és maguk a szociális munkások sem értettek a növénytermesztéshez vagy kisállattartáshoz. A kezdeményező szociális szakemberek tulajdonképpen meg- és újratanulták a klienseikkel együtt a termelési folyamatokat. A közös tanulási folyamat, a személyes kapcsolatok és intenzív együttműködés pedig megerősítette mind az irányítók, mind a résztvevők elköteleződését és motivációját a program sikeréért.

Az elköteleződést és motivációt tovább erősíti, hogy a program projektformában müködik, és ezért évröl évre látható és elszámolható eredményt kell felmutatnia. A másik fontos elem, hogy a részvétel önkéntes. A szociális munkások és klienseik együttműködése a feltétele a projekt sikerének, ami kölcsönösséget teremt az alapvetően inkább hierarchikus viszonyban lévő szociális munkások és klienseik között.

A szociális földprogram sikeres és elismert programjává vált a városnak, számos más kistelepülési program számára is jó példaként szolgál. Sikere azonban túlmutat a projekt eredményein. A részt vevő szegények esetében a termelés, a termelőmunka a helyi közösség elismerését váltja ki. Az önálló és önkéntes termelőmunka elfogadottságán keresztül jön létre és erősödik meg az „érdemesség” elismerése a résztvevőkben és a helyi társadalomban is. A közös földhasználat és közös projekt közösséget teremt, illetve bizonyos fokig integrálja vagy visszaintegrálja a leszakadó családokat a helyi közösségbe.

„Na akkor láttuk, hogy ez már aztán nagyon nagy, tehát itt már közösségépítést is célszerű lenne belevinni, és akkor záró programot szerveztünk [...] Sátrakat állítottunk fel odakint, együtt ünnepeltük a termést, mikor a krumpli betakarítása volt, minden egyes résztvevőnek, az összes családnak, mindegy, hogy saját kertjében vagy önkormányzati területen müvelte, oklevelet adtunk, mindegyiknek, aki végigvitte.” (interjú, programirányító)

Az irányítók számára pedig a projekt sikere nem egyszerủen a tevekénységük és munkájuk eredményének elismerését jelenti, de hozzájárul helyi hatalmi pozícióik megszerzéséhez és megszilárdításához is. A szociális földprogramot irányító 
szociális munkások a helyi politikai hatalmi hálózatok fontos szereplőivé váltak. A központ vezetője 2014-től a városi képviselőtestület tagja.

A szociális földprogram és eredményei mást jelentenek a részt vevő szegények, a vezetők, illetve a helyi társadalom nézőpontjából, összességében azonban elmondható, hogy a közösség, az identitás és a szegénységkép szempontjából jelentős eredménye, hatása van. A szegények esetében a szociális földprogramban való részvétel megerósíti a munka ethoszát, valamint a tanulás és újratanulás folyamatán keresztül az agrártevékenységekhez való kötődést és ezek értékké tételét. A termelö munka és földhasználat új identitást és a helyi közösségbe való integrálódás lehetőségét kínálja.

„Mi ugye itt magunkban, tehát, hogy önállóan dolgozunk itt a földeken, de ugye, ha valaki nem csinálja jól, nem gondozza a saját földjét, azt mindnyájan megérezzük. Például az elején, a kezdet kezdetén még volt egy ember, aki nem csinálta, tehát nem védekezett a kártevők ellen, és el is fertőződött a kert, és nemcsak az ővé, hanem a szomszédoké is... Szóval az elején még voltak ilyenek, akik nem csinálták rendesen, de ők már nincsenek itt, most már aki itt van, mindenki rendesen csinálja, ez egy jó csapat...” (interjú, résztvevő)

A helyi társadalom szemszögéből a szociális földprogram létrehozza és megerősíti az érdemes (és érdemtelen!) szegények képzetét, akiket lehet integrálni a helyi társadalomba, a mezőgazdasági munkán, a paraszti hagyományokon keresztül. Ugyanakkor ezzel párhuzamosan a szegények egy másik - a programban részt nem vevő - csoportjának kirekesztését is tovább erősíti.

A hajdúnánási szociális földprogram, mind a tartalmát, mind a folyamatát, mind pedig a kimenetelét tekintve megfelel a társadalmi innováció kritériumainak. Tartalmát tekintve innovatív, hisz helyi viszonylatban új eszközzel, a közösségi földhasználat és mezőgazdasági termelés eszközével a szegénység problémájának enyhítését célozza. Folyamatát tekintve innovatív, hisz új típusú kapcsolatokat, a szociális problémák kezelésének új, együttmüködésen és kooperáción alapuló formáit hozza létre. Végezetül pedig kimenetelében is innovatív, hisz bár csak a helyi szegények egy szűk rétege számára, de mégis az integráció és részvétel új lehetőségét termeti meg.

Az önkormányzati szervezésü földhasználati program olyan társadalompolitika része, amelyben számos szereplőcsoport érdeke találkozik. A bemutatott eset jól elhelyezhető egy olyan modellben, amelyben egyértelmüen megadható, hogy a szegények egy csoportjának az innovatív földhasználati programba történő bevonása milyen érdekek szerint történik, és a szereplő csoportoknak milyen közvetlen és áttételes hasznuk származik ebböl (1. ábra). Az uralkodó kormányzati elit az elosztás és újraelosztás rendszerein keresztül teremt politikai stabilitást, és pacifikálja a potenciális elégedetleneket. A példánkban 


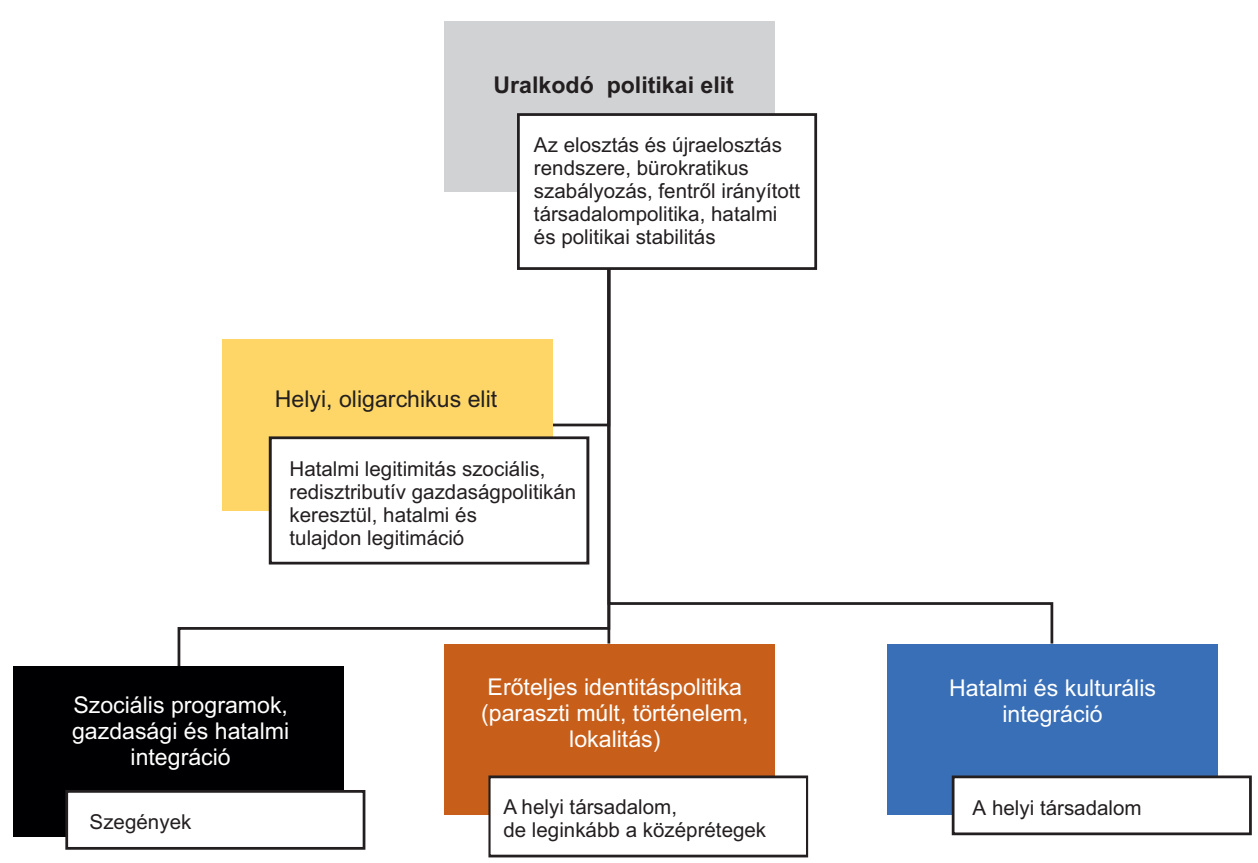

1. ábra. Szereplők és érdekek

szereplő programokkal egyrészt klienssé teszik az élelmiszertermelésbe kapcsolódó rászorultakat, másrészt a szegényeknek a programból kimaradó jelentős számú csoportjait is függő helyzetbe hozzák, hiszen azok is belépnének a kedvezményezett résztvevők közé. Az érdemesek és az időlegesen érdemtelennek nyilvánítottak az alternatívák teljes hiánya miatt elsődlegesen érdekeltek a programok, tágabb értelemben a projektekkel kivitelezett rend fenntartásában. Az állam úgy teremt társadalmi és hatalmi stabilitást, hogy ahhoz igen csekély forrásokat használ fel. Olyan fentről irányított bürokratikus rendszer ez, amely nagyon kevés forrás mozgósításával és közvetlen erőszak alkalmazása nélkül, viszonylag kis létszámú adminisztrációval éri el a nyomorgók társadalom alján tartását. Az ily módon fenntartott stabilitás az uralkodó elit elsődleges haszna. A szegények érdekei teljes kiszolgáltatottságukra vezethetők vissza. A 20-25 zsák krumpli vagy más csekélyke élelem valamennyire enyhíti az éhezést. A programban részt vevők társadalmi elismerése az ellenkezés és a kétely időszaka után a visszaintegrálódás illúzióját is megteremti, ami úgyszintén hozzájárul a rendszer legitimációjához, elfogadásához. A helyi elit saját hatalmi pozícióinak legitimálását segíti a szegénységi programokkal. A résztvevő és a részvétel lehetőségére váró szegények leginkább a helyi hatalmi elit kliensei. Husz Ildikó hívja fel a figyelmet arra, hogy a szegénység elleni pro- 
jektekben gyakran a helyi erőcsoportokhoz tartozó középosztály tagjai kapnak alkalmazást (Husz, 2018). A helyi közigazgatás vezetése a szociális programok sikerével prezentálja pozíciójának érdemességét és hasznát. A szegények a társadalmi és hatalmi stabilitás, a kisebb települések többségében oligarchikusan összefonódó közigazgatási és gazdasági elit tulajdonbiztonságát is szolgálja. A társadalmi integráció, amelynek fontos eleme a szegények pacifikálása, valójában megfelel a helyi társadalom legtöbb csoportja érdekeinek. A szegények élelemhez vagy más programokban kiegészítö jövedelemhez jutnak, elfogadott és nem diszkriminált tagjai a helyi társadalomnak. A kistelepüléseken és a kisvárosokban a társadalom politikai integrációjának erőteljes eleme az identitáspolitika, a lokális identitás újratermelése elsődleges a paraszti múlt elemeinek a felhasználásával (Csurgó, 2014; Csurgó-Szatmári, 2014). A nyomorát paraszti jellegủ munkavégzéssel enyhítő szegény tökéletesen illik a neoparaszti, lokális közösségi identitáshoz, amelyet a helyi társadalom a jelek szerint a legfontosabb identitáselemként fogad el. A középosztály (és a kulturális elit) aktívan vesz részt az identitás újraformálásában, és az az erre szolgáló projektekből még forrásokhoz is jut. A hatalmi és kulturális integráció, amelyben a szegénység elleni programoknak lényeges gyakorlati és szimbolikus funkciójuk van, a helyi társadalom szinte összes csoportjának az érdeke és haszna.

\section{IRODALOM}

Czibere I. (2013): Projektek a szervezetekben. In: Czibere I. - Kovách I. (szerk.): Fejlesztéspolitika, vidékfejlesztés. Debrecen: Debreceni Egyetemi Kiadó, 107-138.

Csurgó B. (2014): A vidék nosztalgiája: Kulturális örökség, turizmus- és közösségszervezés három észak-alföldi kistérségben, socio.hu: Társadalomtudományi Szemle. 4, 2, 1-20.

Csurgó B. - Szatmári A. (2014): Vidéki kultúra, helyi közösség és lokális identitás: A kulturális örökség szerepe a lokális identitásépítésben és a helyi közösségfejlesztésben Hajdúdorogon és Hajdúhadházon. Metszetek - Társadalomtudományi Folyóirat, 3, 33-51.

Franklin, A. I. - Kovách I. - Csurgó, B. (2017): Governing Social Innovation: Exof 'Discretionary Practice' in the Negotiation of Shared Spaces of Community Food Growing. Sociologia Ruralis. 57, 4, 439-458.

Hillier, J. (2013): Towards a Deleuzean-inspired Methodology for Social Innovation Research and Practice. In: Moulaert, F. - MacCallum, D. - Mehmood, A. et al. (eds.): The International Handbook on Social Innovation. Edward Elgar, 169-180.

Husz I. (2018): Szegénységcsökkentést célzó programok és a projektfoglalkoztatás. Magyar Tudomány, 179, 6, 871-884. ez a szám

Kovách I. (2016): A földből élők és földhasználati módok Hajdúnánáson. In: Kovács K. (szerk.): Földböl élők: Polarizáció a magyar vidéken. Budapest: Argumentum Kiadó, 472-493.

Kovách I. - Kucerova, E. (2006): The Project Class in Central Europe: The Czech and Hungarian Cases. Sociologia Ruralis. 46, 3-21.

Kovách I. - Kucerova, E. (2009): The Social Context of Project Proliferation - The Rise of a Project Class. Journal of Environmental Policy and Planning, 11, 3, 203-221. 
Levesque, B. (2013): Social Innovation in Governance and Public Management Systems: Towards a New Paradigm? In: Moulaert, F. - MacCallum, D. - Mehmood, A. et al. (eds.): The International Handbook on Social Innovation. Edward Elgar, 25-39.

Moulaert, F. - Martinelli, F. - Swyngedouw, E. et al. (2005): Towards Alternative Model(s) of Local Innovation. Urban Studies, 42, 1969-1990.

Pradel Miquel, M. - Cabeza, M-G. - Anglada, S-E. (2013): Theorizing Multi-level Governance in Social Innovation Dynamics. In: Moulaert, F. - MacCallum, D. - Mehmood, A. et al. (eds.): The International Handbook on Social Innovation. Edward Elgar, 155-168.

Sjöblom, S. (2006) Towards a Projectified Public Sector - Project Proliferation as a Phenomenon. In: Sjöblom, S. - Andersson, K. - Ecklund, E. - Godenhjelm, S. (eds.): Project Proliferationand Governance. Helsinki: Helsinki University Press, 9-33. 